\title{
EFFECT OF NANO FERTILIZATION, CHEMICAL AND HUMIC ACID ON THE VEGETATIVE GROWTH, CHEMICAL COMPOSITION AND OIL YIELD OF CUMINUM CYMINUM L.
}

\author{
H.M. El-Labban ${ }^{(1)}$, Fardous Menesy ${ }^{(2)}$, Shadia A.Kotb ${ }^{(3)}$, M. I. Fetouh ${ }^{(1)}$ \\ and Neveen M. Naga ${ }^{(3)}$ \\ (1) Horticulture Dept., Fac. of Agric., Tanta Univ. \\ (2) Horticulture Dept., Fac. of Agric., Kafr El Sheikh Univ. \\ (3) Horticulture Research Institute.
}

Received: Sep. 21, 2016

Accepted: Oct. 10,2016

\begin{abstract}
This experiment was carried out at a private farm near El-Mahalla: Gharbieah Governorate during the two successive seasons of 2013/2014 \& 2014/2015 to study the effect of different levels of fertilization and nano-particles fertilizer on the vegetative growth, chemical composition and essential oil yield of Cuminum cyminum L. plants. Silicon and graphite nanoparticles were applied to cumin plants by spraying at three levels of 20, 40 and $60 \mathrm{mg} / \mathrm{l}$ two times. The resultes showed that, using $75 \%$ NPK dose + humic acid and $60 \mathrm{mg} / \mathrm{l}$ nano graphite gave the highest values of growth parameters, (plant height, number of both branches and umbels/ plant) while the treatment of $75 \%$ NPK dose $+2 \mathrm{~g} /$ plant humic acid and $40 \mathrm{mg} / \mathrm{l}$ nano graphite gave the highest values of chlorophyll $a$ and $b$. The treated plants with $100 \%$ NPK and $20 \mathrm{mg} / \mathrm{l}$ nano silica gave the highest values of $N$ and $P$ percentages. While, the highest $K \%$ and oil \% were obtained by using $100 \%$ NPK dose and $60 \mathrm{mg} / \mathrm{l}$ nano graphite. For the major identified components in the oil were p-menta-1-en 7-al from using $75 \%$ NPK $+2 \mathrm{~g} / \mathrm{plant}$ humic acid with $40 \mathrm{mg} / \mathrm{l}$ nano silica. It can be recommended to apply $75 \%$ NPK dose $+2 \mathrm{~g} / \mathrm{plant}$ humic acid and/ or $100 \%$ NPK with $60 \mathrm{mg} / \mathrm{l}$ nano graphite for both to obtain the highest vegetative growth parameters and essential oil yield of Cuminum cyminum $L$.
\end{abstract}

Key words: Nano fertilization, NPK fertilization, Cuminum cyminum

\section{INTRODUCTION}

Cuminum cyminum Linn. is an annual plant of the family-Apiaceae commonly known as cumin. The medicinal component of the plant is cumin oil extracted from the ripe fruit. In folk medicine, cumin is used as a carminative for stomach disorders, diarrhea, and colic, as well as particularly in veterinary medicine (Gruenwald et al., 2004). The oil is especially used as a carminative and as a stringent (Baytop, 1989). The fruits of C. cyminum L. are used as a traditional flavouring in a number of ethnic cuisines and food industries. Moreover, cumin oil shows a high antifungal activity against various pathogenic fungi, and effective high antibacterial activity. Therefore, it is also used as a fumigant or additive in the storage of food tuffs ( $\mathrm{Li}$ and Jiang, 2004). The cumin fruits contain volatile oil (2-5\%) that impart the characteristic aroma to the fruits (Behera et al., 2004).

Application of NPK at certain rates plus organic fertilizer or humic acid gave the best results for increasing growth and yield as well as oil (\%) in medicinal and aromatic plants. Such results were obtained by (Said et al, 2015 on Hibiscus sabdariffa L).

Humic acid is known to improve nutrient retention in the growing media and increasing the water holding capacity (Dorer and Peacock, 1997).

Nanotechnology is considered as a potential solution for increasing the value of agriculture products and environmental problems. For example, with the use of nano particles and nano powders, researches can 
produce controlled or delayed release fertilizers (Kottegoda., et al., 2011).

Nanoparticles can improve the physical and chemical properties of the soil which were reflected on the plant growth (Amin et al., 1999). Silica nano particles increase turgor pressure and plant size by improving water use efficiency and leaf relative water content (Rawson et al., 1988).

The aim of this investigation was to study the effect of different levels of fertilization and nano- fertilizer on the vegetative growth, chemical composition, essential oil yield and components of Cuminum cyminum plants.

\section{MATERIALS AND METHODS}

This experiment was carried out at a private farm near El-Mahalla: Gharbieah Governorate during the two successive seasons of 2013/2014 \& 2014/2015 to study the effect of different levels of fertilization and Nano- fertilizer on the vegetative growth, chemical composition, oil yield and components of Cuminum cyminum L. plants. The physical and chemical properties of the experimental soil are shown in Table (1).
This experiment included 21 treatments as follows:

\section{A-NPK treatments:}

1- NPK full dose (control).

2- $75 \%$ NPK dose + humic acid (2gm/plant).

3- $50 \%$ NPK dose + humic acid (4gm/plant).

\section{B- Nano particles treatments:}

1. Without nano (control)

2- $20 \mathrm{mg} / \mathrm{l}$ silica NPs

3- $40 \mathrm{mg} / \mathrm{l}$ silica NPs

4- $60 \mathrm{mg} / \mathrm{l}$ silica NPs

5- $20 \mathrm{mg} / \mathrm{l}$ graphite NPs

6- $40 \mathrm{mg} / \mathrm{l}$ graphite NPs

7- $60 \mathrm{mg} / \mathrm{l}$ graphite NPs

TEM imaging of the prepared nanoparticles revealed a spherical shape of the particles, with an average size of 23.48- $45.04 \mathrm{~nm}$ of silicon and .20- $15.34 \mathrm{~nm}$ of graphite are shown in fig $1,2$.

These treatments were arranged in a split plot design with three replications. NPK and humic acid treatments were randomly arranged in the main plots and nano particles concentrations were randomly distributed in the sub plots.

Table (1): Physical and chemical analysis of the experimental soil.

\begin{tabular}{|c|c|c|c|c|c|c|c|c|c|c|}
\hline \multicolumn{6}{|c|}{ Physical Properties } & \multicolumn{5}{|c|}{ Chemical Properties } \\
\hline Caco3 & C.sand\% & F.sand\% & Silt\% & Clay\% & Texture & $\begin{array}{c}\text { Ec } \\
\text { dsm-1 } \\
\end{array}$ & $\begin{array}{c}\mathrm{N} \text { (avail) } \\
\text { Ppm }\end{array}$ & $\begin{array}{c}\mathrm{P} \text { (avail) } \\
\mathrm{ppm}\end{array}$ & $\begin{array}{c}\mathrm{K} \text { (avail) } \\
\mathrm{ppm}\end{array}$ & O.M\% \\
\hline 3.57 & 4.12 & 21.52 & 25.11 & 49.25 & Clayly & 1.78 & 82.05 & 9.22 & 720 & 1.53 \\
\hline
\end{tabular}

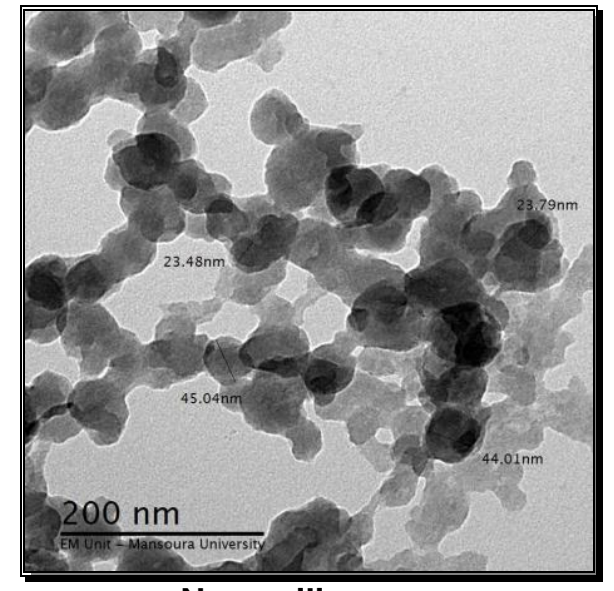

Nano silicon

Fig (1)

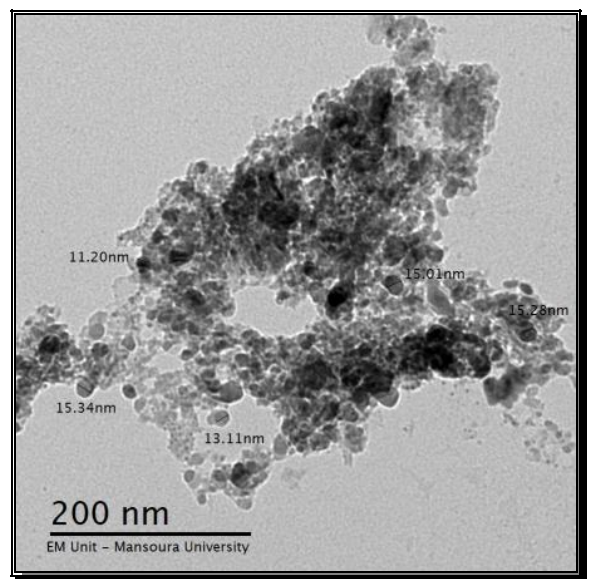

Nano graphite

Fig (2)

Fig 1,2: TEM imaging of the prepared nanoparticles. 
Chemical fertilizers were ammonium sulphate $\quad(20.5 \% \quad \mathrm{~N}), \quad$ calcium superphosphate $\left(15.5 \% \quad \mathrm{P}_{2} \mathrm{O}_{5}\right)$ and potassium sulphate $\left(48 \% \mathrm{~K}_{2} \mathrm{O}\right)$ at the rate of 150,150 and $50 \mathrm{~kg} / \mathrm{fed}$ respectively, as a full dose of NPK (recommended dose). Humic acid and calcium super phosphate were applied at one dose during the preparation of soil before planting, while ammonium sulphate and potassium sulphate were divided into two equal doses. The first dose was added after 45 days from planting, and the second one was added one month later in the two experimental seasons.

The seeds were sown in the open field on Dec $16^{\text {th }}$ in the two seasons, respectively. Plants were twice sprayed with freshly prepared solution of silicon NPs and graphite NPs after 45 days from planting and then before the flowering.

The data at the end of each season were recorded on April $24^{\text {th }}$ as follows:

\section{A- Plant growth characters:}

Plant height $(\mathrm{cm})$, number of both branches and umbels/ plant, plant dry weight $(\mathrm{g})$, seeds yield weight ( $\mathrm{g} / \mathrm{plant})$ and weight of 1000 seeds $(\mathrm{g})$.

\section{B- Chemical composition:}

1- Chlorophyll 'a', 'b' and carotenoids were described by Wellburn (1994).

2- The $N, P$ and $K$ elements were determined in the dried powdered herb according to Black (1983), Watanabe and Olsen (1965) and Richards (1954), respectively.

3- Volatile oil percentage was determined in ripe dry fruits according to Guenther et al. (1960).

4- The obtained volatile oil were analysed using Dschrom. Model HP-5890 with flame ionization detection that was fitted with capillary column, coated with carbowax $20 \mathrm{M} \times 0.2 \mathrm{~min}$. The operating conditions were injector temperature $250^{\circ} \mathrm{C}$, detector temperature $300^{\circ} \mathrm{C}$. Nitrogen was used as a carrier gas with flow rate $1 \mathrm{ml} / \mathrm{min}$, for hydrogen was 30 $\mathrm{ml} / \mathrm{min}$. The peaks were recorded and the areas under peaks were determined using HP- intergrator. Oil components were identified by comparing the retention times with that of the authentic compounds.

\section{Statistical analysis:}

The obtained data were subjected to statistical analysis of variance according to Snedecor and Cochran (1980), and means separation were compared according to LSD at $5 \%$ level.

\section{RESULTS AND DISCUSSION 1- Plant height, number of branches and number of umbels/ plant:}

Data in Tables (2 to 4) showed that plant height was significantly affected by mineral fertilizers in the first season only. Using $75 \%$ NPK dose $+2 \mathrm{~g} /$ plant humic acid gave the tallest plants, the highest number of branch and umbels/ plant with non significant differences between $100 \%$ NPK and $75 \%$ $\mathrm{NPK}+2 \mathrm{~g} /$ plant humic acid. On the other hand, using $50 \%$ NPK dose +4g/plant humic acid recorded the least values in this respect.

It could be concluded that, using 75 $\% N P K+2 g /$ plant humic acid gave the best values of plant height, both branch and umbels number which may be attributed to the role of humic acid in improving nutrients retention in the growing medium and increasing the water holding capacity (Dorer and Peacock, 1997).

Concerning nanoparticles treatments, data presented in Table (2, 3 and 4) showed that plant height, branch and umbels number were significantly affected by nanoparticles in both seasons. The tallest Table plants were resulted from the sprayed plants with all rates of either nano graphite or $20 \mathrm{mg} / \mathrm{l}$ nano silicon in the first and second seasons, respectively while the highest number of umbels/ plant were obtained by using 20 and 40 silica NPs in the $1^{\text {st }}$ and $2^{\text {nd }}$ seasons, respectively. On the other hand, the shortest plants, the lowest branch and umbels number were obtained by $60 \mathrm{mg} / \mathrm{l}$ nano silicon in the $1^{\text {st }}$ season and the control treatment in the $2^{\text {nd }}$ season. 


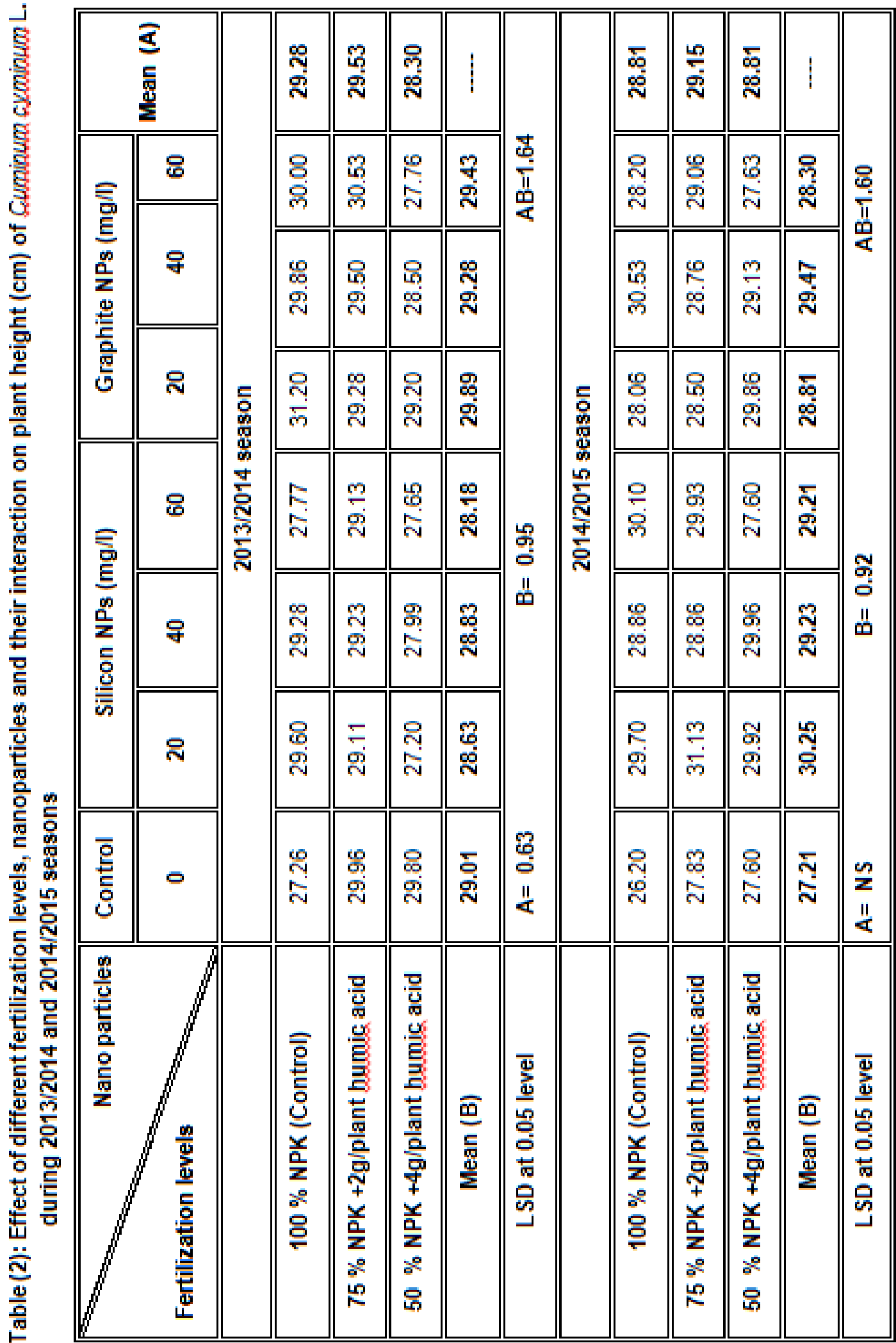




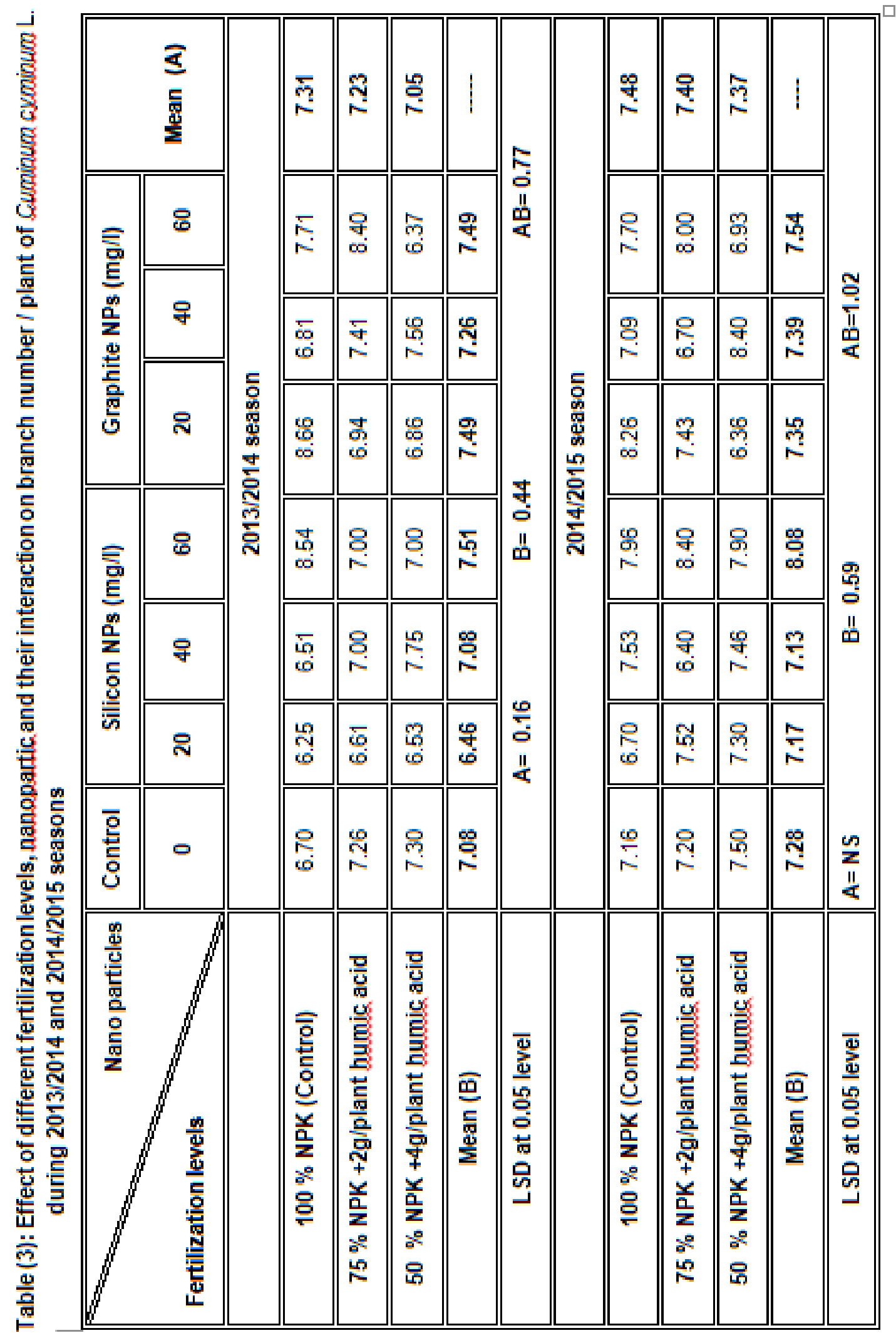




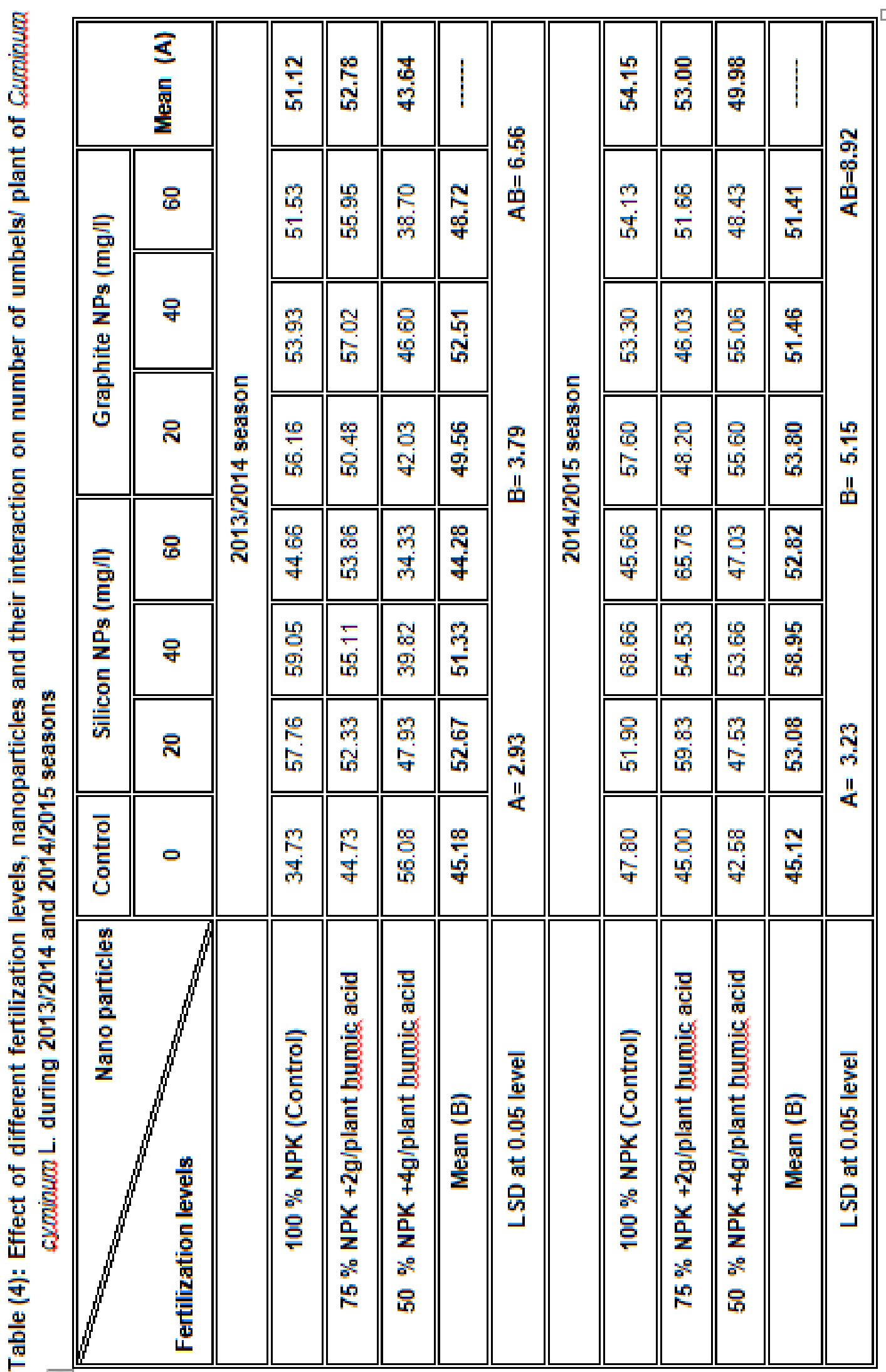




\section{El-Labban}

These results may be attributed to nanoparticles effect in a number of crops in enhancing germination and seedling growth, physiological activities, gene expression and protein level indicating their potential use in crop improvement (Kole, et al., 2013).

The data in Tables (2 to 4) revealed that the interaction between fertilization treatments and foliar spraying of nanoparticle showed significant effects on plant height and number of both branches and umbels in both seasons. In the first season, the tallest plants were resulted from plants received $100 \%$ NPK 20 nano graphite or $75 \% \mathrm{NPK}+2 \mathrm{~g} / \mathrm{l}$ humic acid as well as $60 \mathrm{mg} / \mathrm{l}$ nano graphite or $100 \% \mathrm{NPK}+60 \mathrm{mg} / \mathrm{l}$ nano graphite without significant differences among themselves. In the second season, the significantly tallest plants resulted from either adding 75 $\%$ NPK $+2 \mathrm{~g} / \mathrm{l}$ humic acid and $20 \mathrm{mg} / \mathrm{l}$ silica NPs or $100 \%$ NPK with $60 \mathrm{mg} / \mathrm{l}$ silica NPs or 40 $\mathrm{mg} / \mathrm{l}$ nano graphite. On the opposite, the significantly shortest plants were resulted from adding $50 \% \mathrm{NPK}+4 \mathrm{mg} / \mathrm{l}$ humic acid and either 20 or $60 \mathrm{mg} / \mathrm{l}$ silica NPs in both seasons, respectively.

Regarding the number of branches, the significantly highest values were resulted in the first season from plants received $100 \%$ NPK with $20 \mathrm{mg} / \mathrm{l}$ graphite NPs or $100 \%$ NPK with $60 \mathrm{mg} / \mathrm{l}$ silica NPs or $75 \%$ NPK $+2 \mathrm{~g} / \mathrm{l}$ humic acid with $60 \mathrm{mg} / \mathrm{l}$ graphite NPs without significant differences among themselves. The highest umbels number/ plant was observed at $100 \%$ NPK with $40 \mathrm{mg} / \mathrm{l}$ silica NPs in the two seasons, respectively. On the other hand, the significantly least values resulted from 100\% NPK with $60 \mathrm{mg} / \mathrm{l}$ silica NPs in both seasons, respectively. The positive morphological effects of nanomaterials included enhancing germination percentage and rate; length of root and shoot, and their ratio; and vegetative biomass. (Amin et al., 1999).

\section{2- Dry weight, yield of seeds/ plant and 1000 seeds weight:}

Data presented in Tables (5 to 7 )

revealed that the significantly highest values of dry weight and seed yield resulted from NPK at full dose (control) in both seasons. On the other hand, using $50 \% \mathrm{NPK}+4 \mathrm{~g} / \mathrm{plant}$ humic acid recorded the significantly least values of plant dry weight and seed yield for the two seasons, respectively. Also, data cleared that the highest values of seed index (1000 seeds weight) resulted from $50 \%$ NPK with 4g/plant humic acid in the first season and $100 \%$ NPK in the second one.

The superiority of NPK in plant dry weight, seeds yield/ plant and 1000 seeds weight/ plant may be due to that chemical fertilizers could enhance plant growth due to the role of nitrogen in nucleic acids and protein synthesis, and phosphorus as an essential component of the energy compounds (ATP and ADP) and phosphoprotein, in addition to the role of potassium as an activator of many enzymes (Helgi and Rolfe, 2005).

Concerning the nanoparticles treatments, data showed that the significantly heaviest dry weight of plants, seeds yield/ plant and 1000 seeds weight resulted from applying $20 \mathrm{mg} / \mathrm{l}$ nano graphite in the $1^{\text {st }}$ season and $40 \mathrm{mg} / \mathrm{l}$ graphite or $40 \mathrm{mg} / \mathrm{l}$ nano silica in the $2^{\text {nd }}$ season, respectively. However, the least values of dry weight, seed yield/plant and 1000 seeds weight resulted from control plants in the first and second seasons,

This result may be attributed to the important role of silicon to be absorbed into plant to increase disease and stress resistance by promoting the physiological activity and growth of the plant. (Agrawal and Rathore, 2014).

The significantly highest values of dry weight resulted from plants received $50 \% \mathrm{NPK}+4 \mathrm{~g}$ /plant humic acid with 20 or $40 \mathrm{mg} / \mathrm{l}$ graphite NPs in the two seasons. The highest values of seed yield/ plant were recorded from $100 \%$ NPK and $40 \mathrm{mg} / \mathrm{l}$ nano graphite, while the highest values of 1000 seeds weight resulted from $75 \% \mathrm{NPK}+2 \mathrm{~g} / \mathrm{plant}$ humic acid $+60 \mathrm{mg} / \mathrm{l}$ silica NPs in both seasons. However, the least values of dry weight and yield of seeds/ plant resulted from plants received $50 \%$ NPK + humic acid 


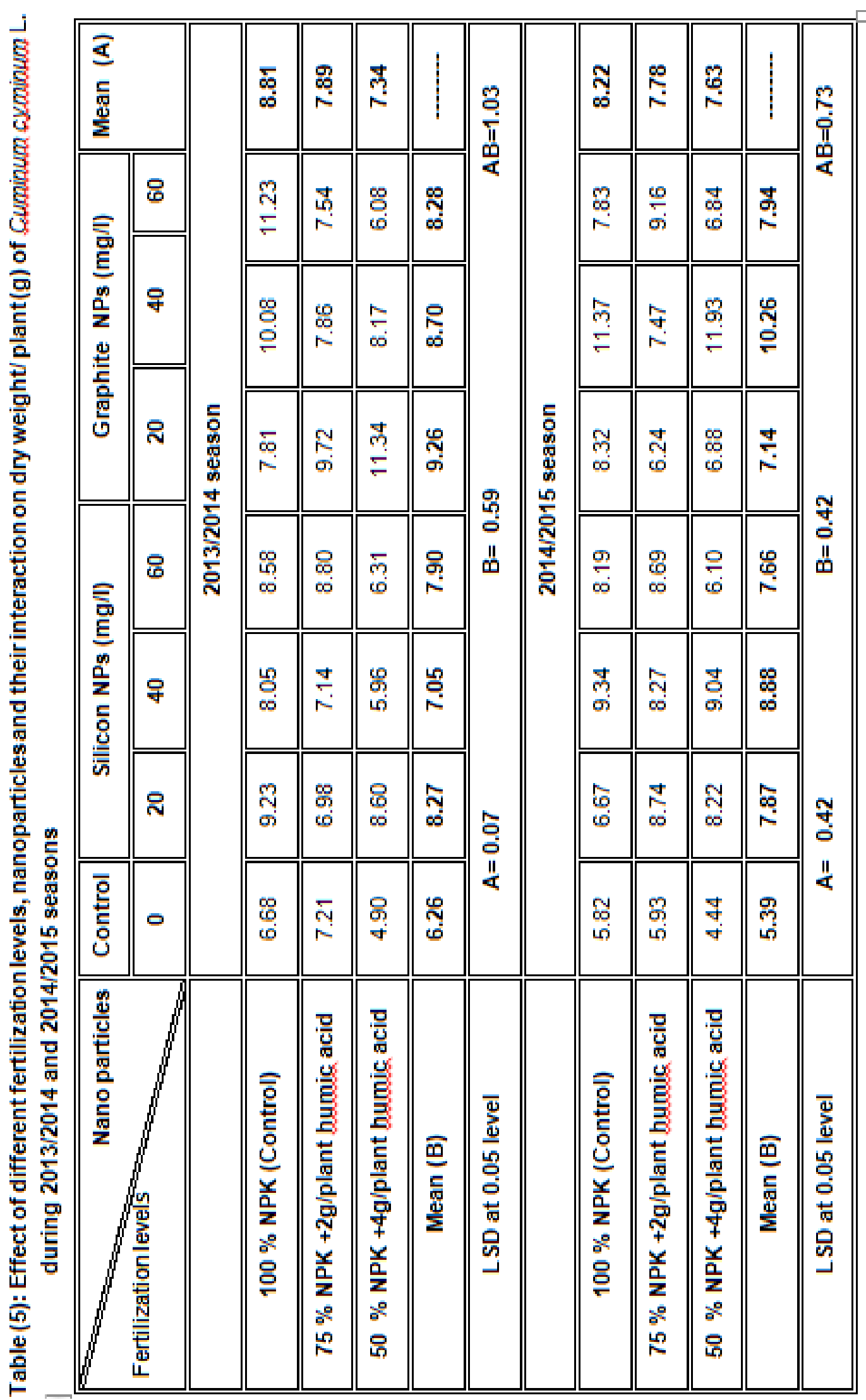




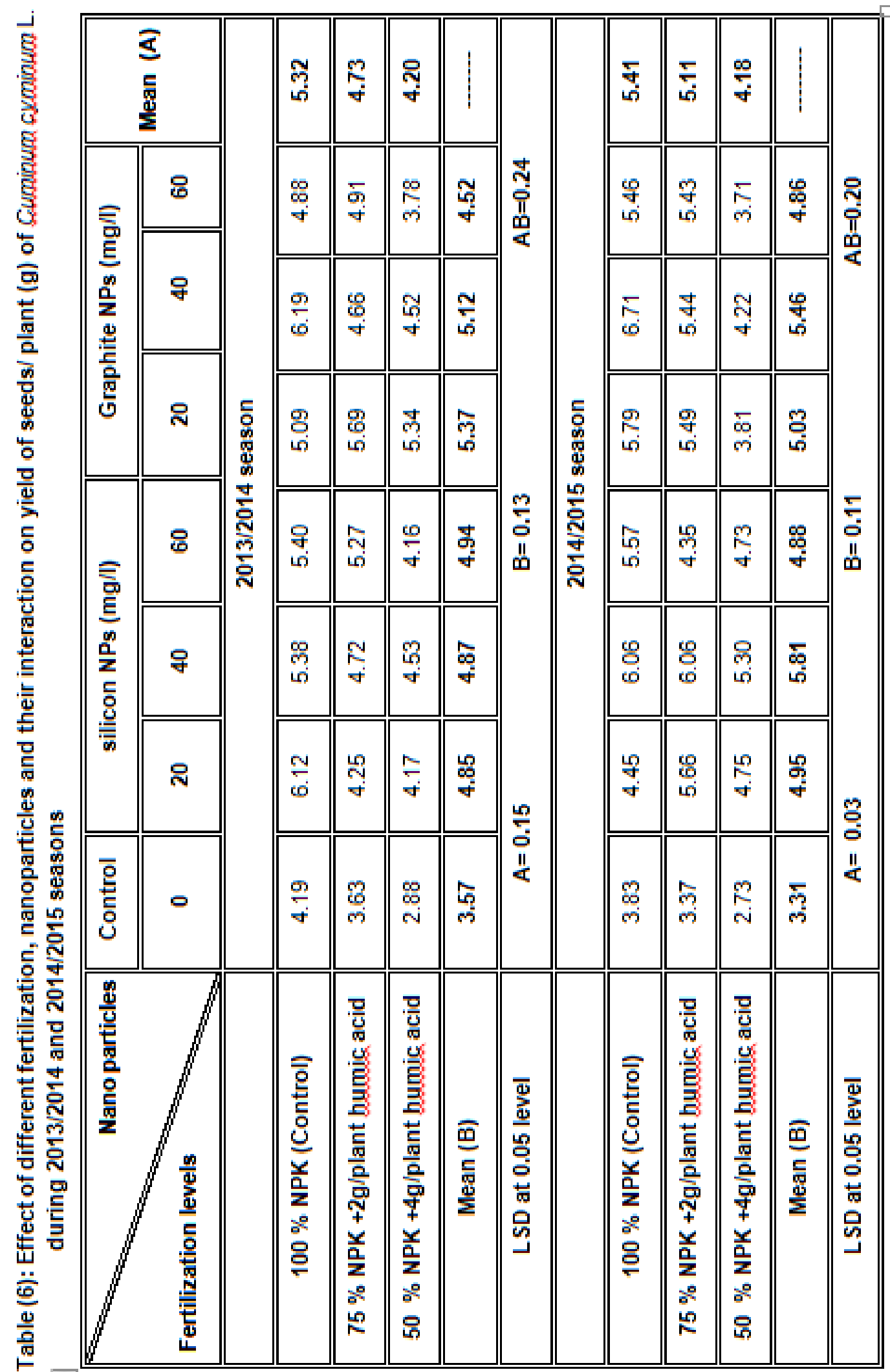


Effect of nano fertilization, chemical and humic acid on the 


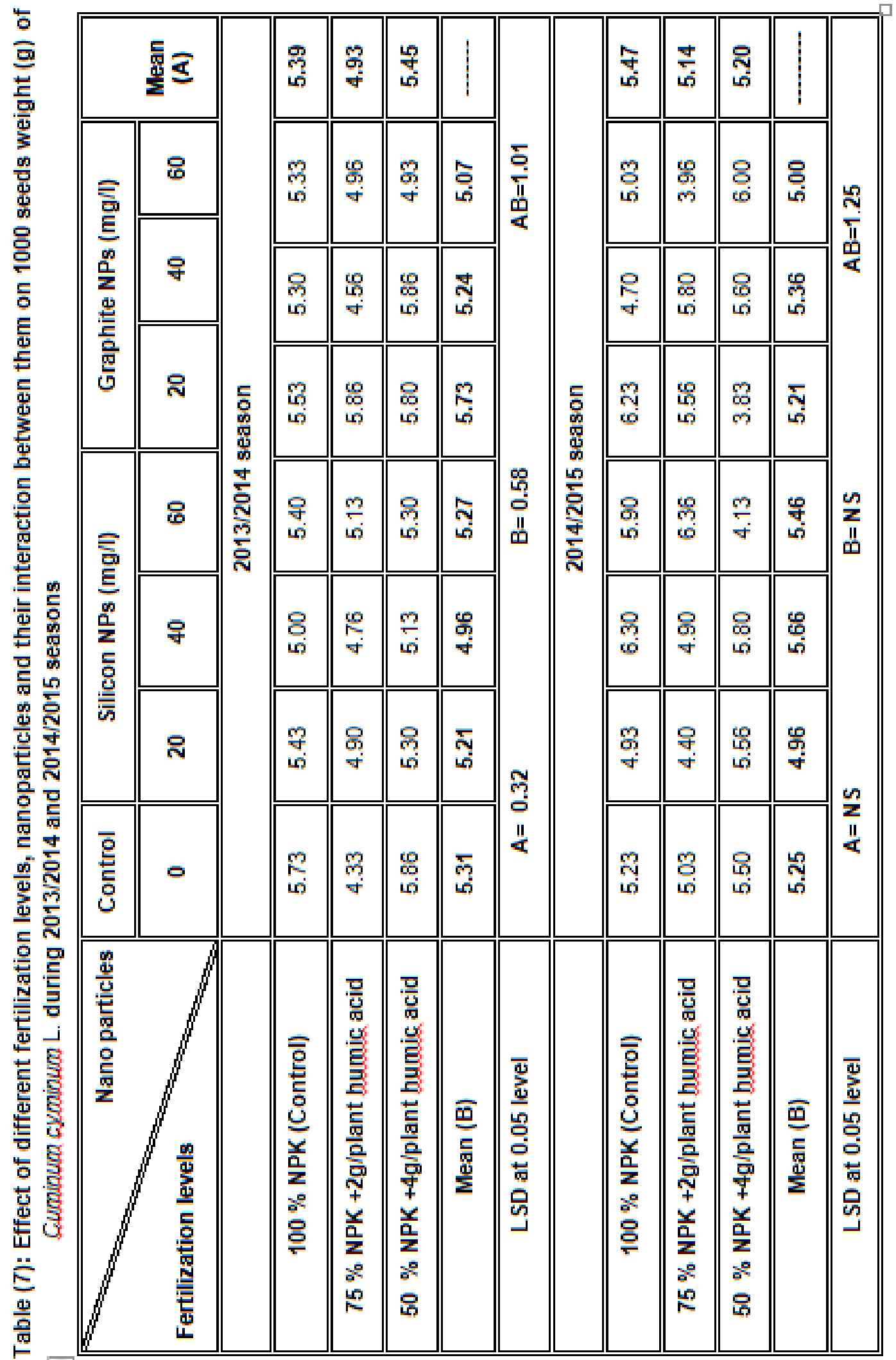


without nanopractices. On the contrary, the least values of 1000 seeds weight were obtained from $75 \% \mathrm{NPK}+2 \mathrm{~g} /$ plant humic acid without nanapractices and $50 \% \mathrm{NPK}+4 \mathrm{~g} /$ plant humic acid with $20 \mathrm{mg} / \mathrm{l}$ nano graphite.

These results may be due to the increment in soil fertility by NPK fertilizer as well as the benefits of humic acid, as improve soil structure and change physical properties of the soil (Chen and Avid, 1990). Also, nanoparticles have enhanced reactivity due to enhanced solubility, greater proportion of surface atoms relative to the interior of a structure, unique magnetic/ optical properties, electronic states, and catalytic reactivity that differ from equivalent bulk materials (Agrawal and Rathore, 2014).

\section{3- Chlorophyll a,b and carotenoides}

Data presented in Tables (8 to10) showed that the highest values of chlorophyll $a, b$ and carotenoides resulted from using $75 \% \mathrm{NPK}+2 \mathrm{~g} / \mathrm{plant}$ humic acid or $50 \% \mathrm{NPK}+4 \mathrm{~g} / \mathrm{plant}$ humic acid in leaf tissues in both seasons. On the opposite, the significantly least values resulted from applying $100 \%$ NPK (control) in both seasons. These results are similar to those of Befrozfar et al. (2013) on Ocimum bacilicum.

Concerning the nanoparticles treatments, generally, data showed that, the significantly highest values of chlorophyll $a, b$ and carotenoides resulted from applying $40 \mathrm{mg} / \mathrm{I}$ silica NPs and $60 \mathrm{mg} / \mathrm{I}$ graphite NPs in the $1^{\text {st }}$ and $2^{\text {nd }}$, respectively.

Data illustrated also that the highest values of chlorophyll (a) resulted from using $50 \% \mathrm{NPK}$ $+4 \mathrm{~g} /$ plant humic acid $+40 \mathrm{mg} / \mathrm{l}$ silica NPs or $75 \% \mathrm{NPK}+2 \mathrm{~g} /$ plant humic acid $+40 \mathrm{mg} / \mathrm{l}$ graphite NPs in the first season. However, treatments of $50 \% \mathrm{NPK}+4 \mathrm{~g} /$ plant humic acid with $60 \mathrm{mg} / \mathrm{l}$ graphite NPs or $50 \% \mathrm{NPK}+4 \mathrm{~g} /$ plant humic acid with $40 \mathrm{mg} / \mathrm{l}$ graphite NPs increased the chlorophyll (a) in the second season. The least values of chlorophyll (a) in the first and second seasons resulted from using $100 \% \mathrm{NPK}+40 \mathrm{mg} / \mathrm{l}$ graphite NPs and $75 \% \mathrm{NPK}+2 \mathrm{~g} / \mathrm{plant}$ humic acid with $40 \mathrm{mg} / \mathrm{l}$ silica NPs in the first and second seasons, respectively. Data cleared also that the best results of chlorophyll (b) were obtained from $75 \% \mathrm{NPK}+2 \mathrm{~g} /$ plant humic acid with $60 \mathrm{mg} / \mathrm{I}$ graphite NPs and $75 \%$ NPK $+2 \mathrm{~g} /$ plant humic acid with $40 \mathrm{mg} / \mathrm{I}$ graphite NPs in the two seasons, respectively. On the contrary, the least values were obtained from using $50 \%$ $\mathrm{NPK}+$ humic acid with $40 \mathrm{mg} / \mathrm{I}$ graphite NPs and $50 \% \mathrm{NPK}+4 \mathrm{~g} /$ plant humic acid with $40 \mathrm{mg} / \mathrm{I}$ silica NPs in the two seasons, respectively. Also, data revealed that, carotenoides showed nearly a similar trend as chlorophyll a, the highest values resulted from $50 \% \mathrm{NPK}+4 \mathrm{~g} / \mathrm{plant}$ humic acid with $40 \mathrm{mg} /$ I silica NPs and $60 \mathrm{mg} /$ I graphite NPs as compared to $100 \%$ NPK with $40 \mathrm{mg} / \mathrm{l}$ graphite NPs and $50 \% \mathrm{NPK}+4 \mathrm{~g} / \mathrm{plant}$ humic acid with $20 \mathrm{mg} / \mathrm{lg}$ graphite NPs in the $1^{\text {st }}$ and $2^{\text {nd }}$ seasons, respectively.

The enhancing effect on chlorophyll a due to applying nanoparticles may be due to that silica nanoparticles increase turgid pressure and plant size by improving water use efficiency and leaf relative water content (Rawson et al, 1988)

This result is similar to those of El-Fouly et al. (2014) on Cordyline terminalis

\section{4- Nitrogen, phosphorous and potassium percentage:}

Data presented in Tables (11 to 13) showed that the applying $100 \%$ NPK gave the highest values of $\mathrm{N}$ and $\mathrm{K} \%$ in the second season, while potassium and phosphorus gave the highest values with $75 \% \mathrm{NPK}+2 \mathrm{~g} /$ plant humic acid in both seasons.

This result is in conformity to Befrozfar et al. (2013) on Ocimum bacilicum. 
Concerning the nano particles treatments, data showed that the significantly highest values of nitrogen (\%) resulted from applying the treatments of 20 


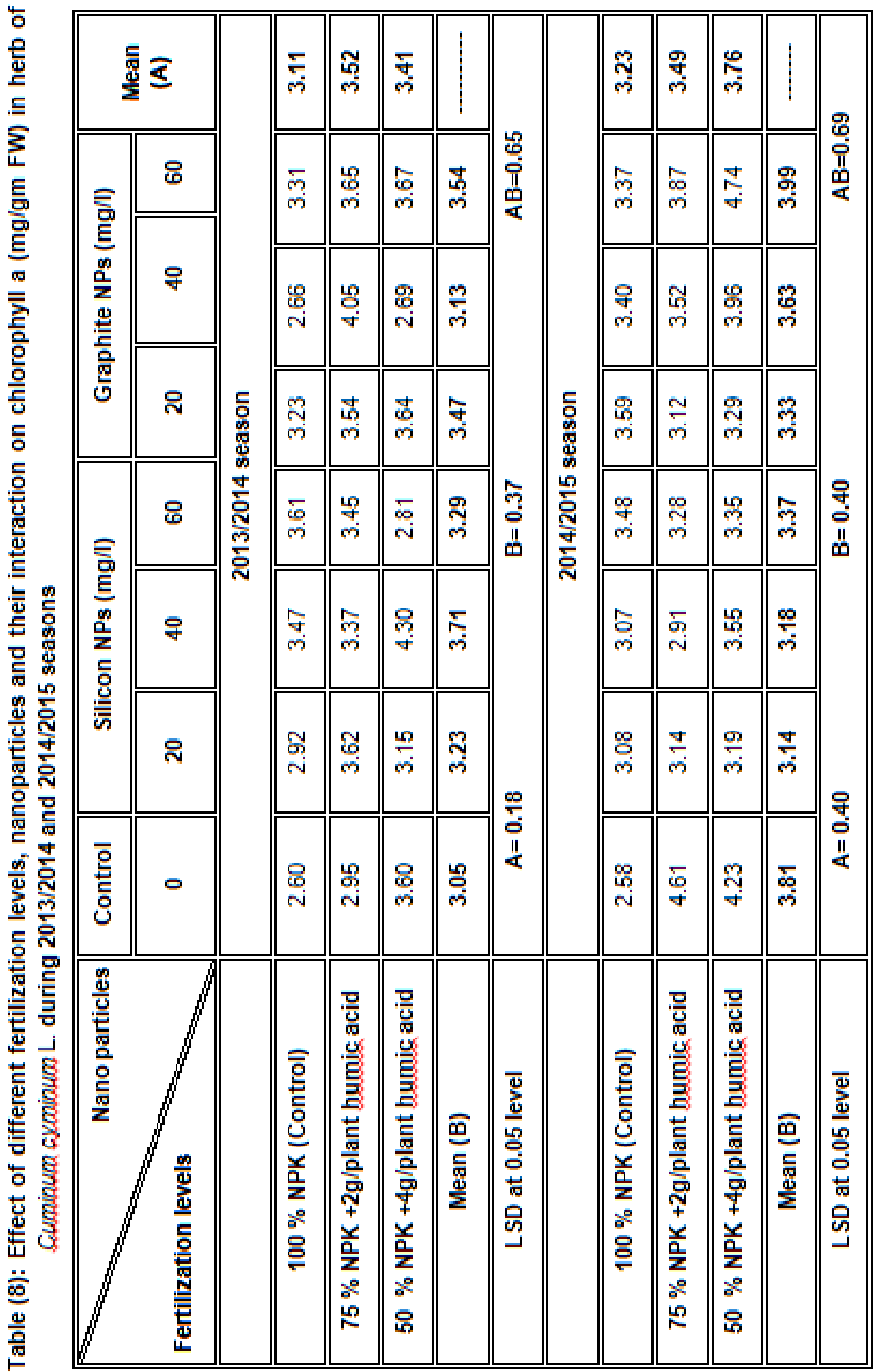




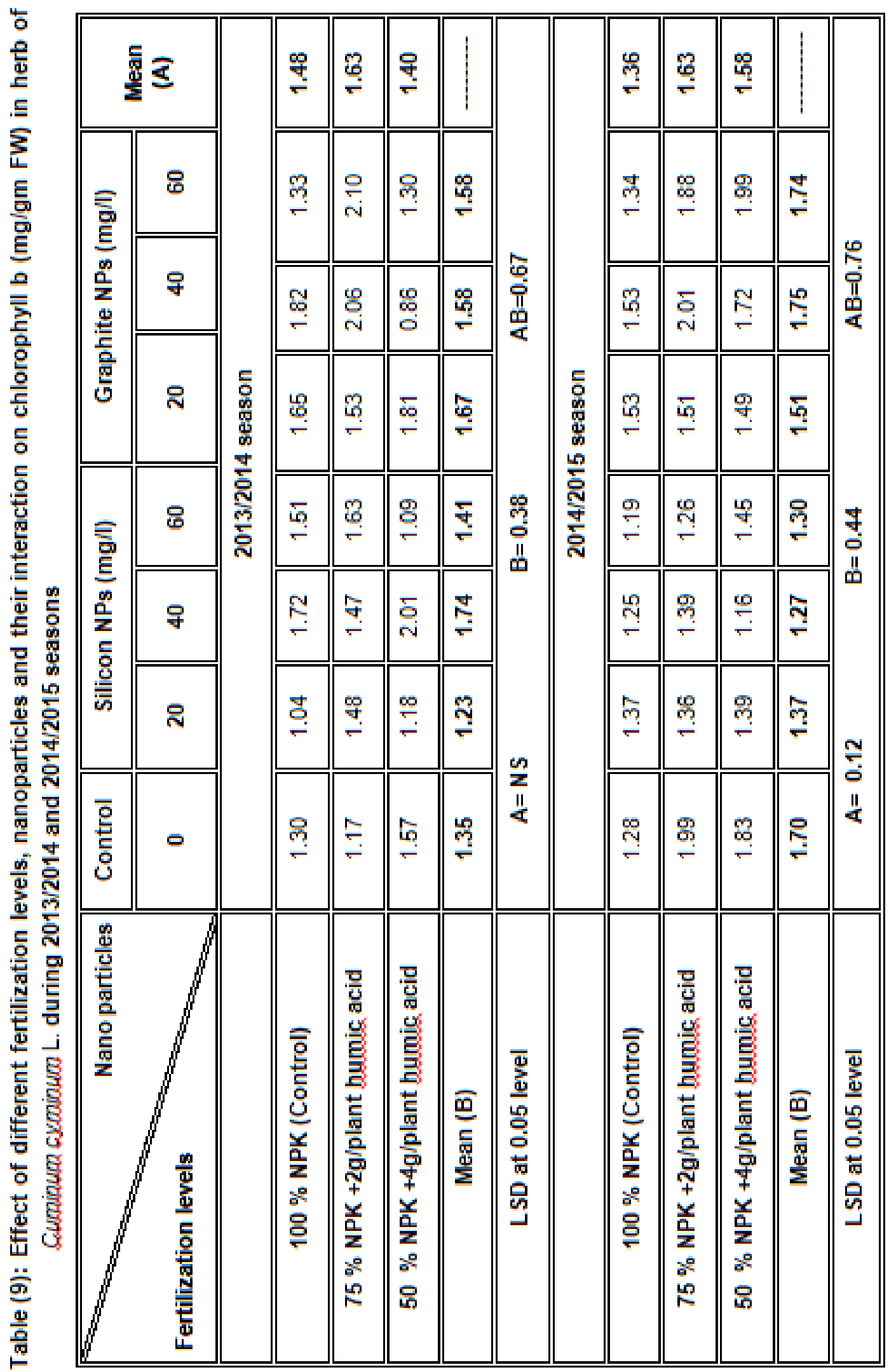




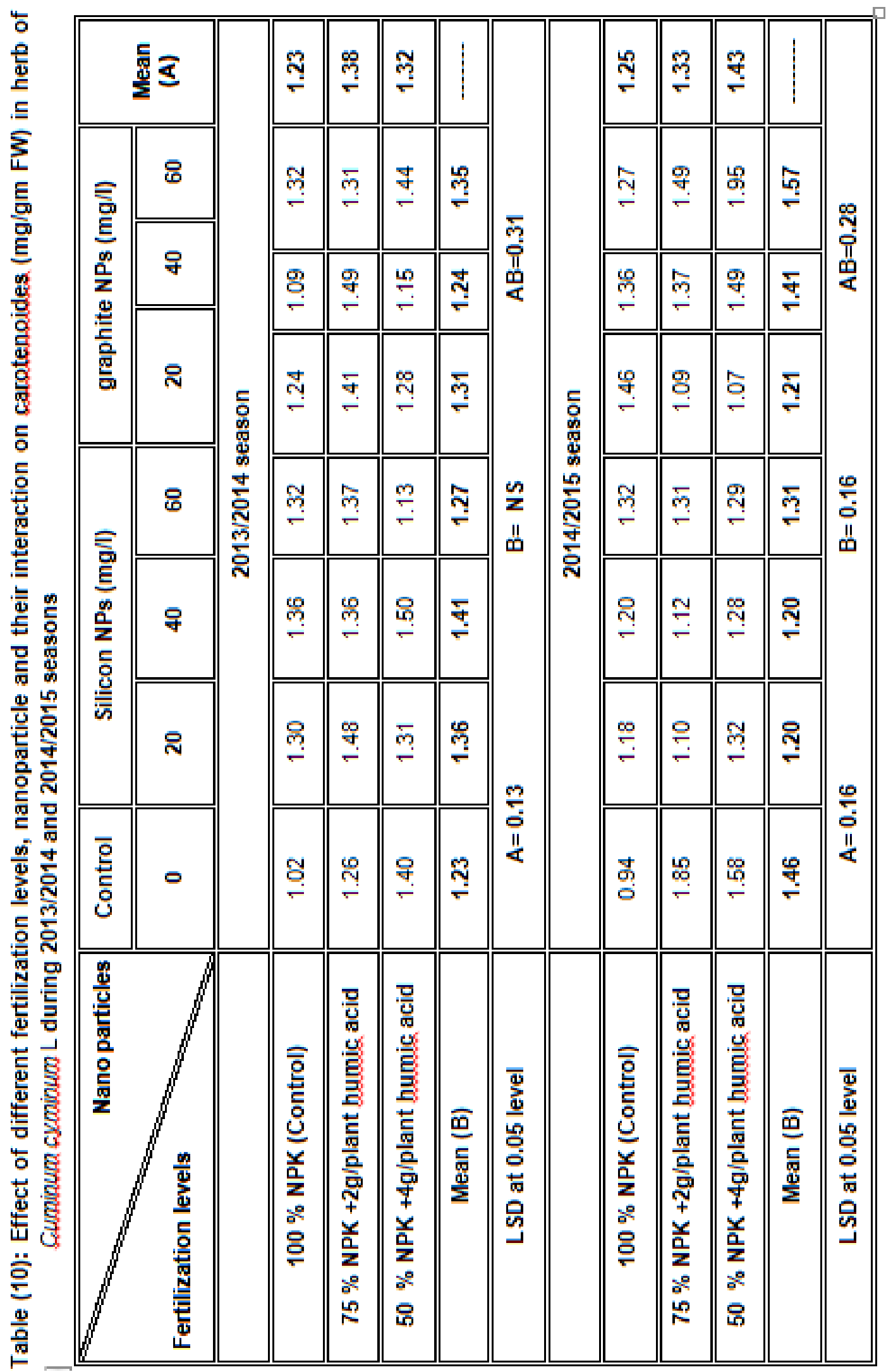


Effect of nano fertilization, chemical and humic acid on the 


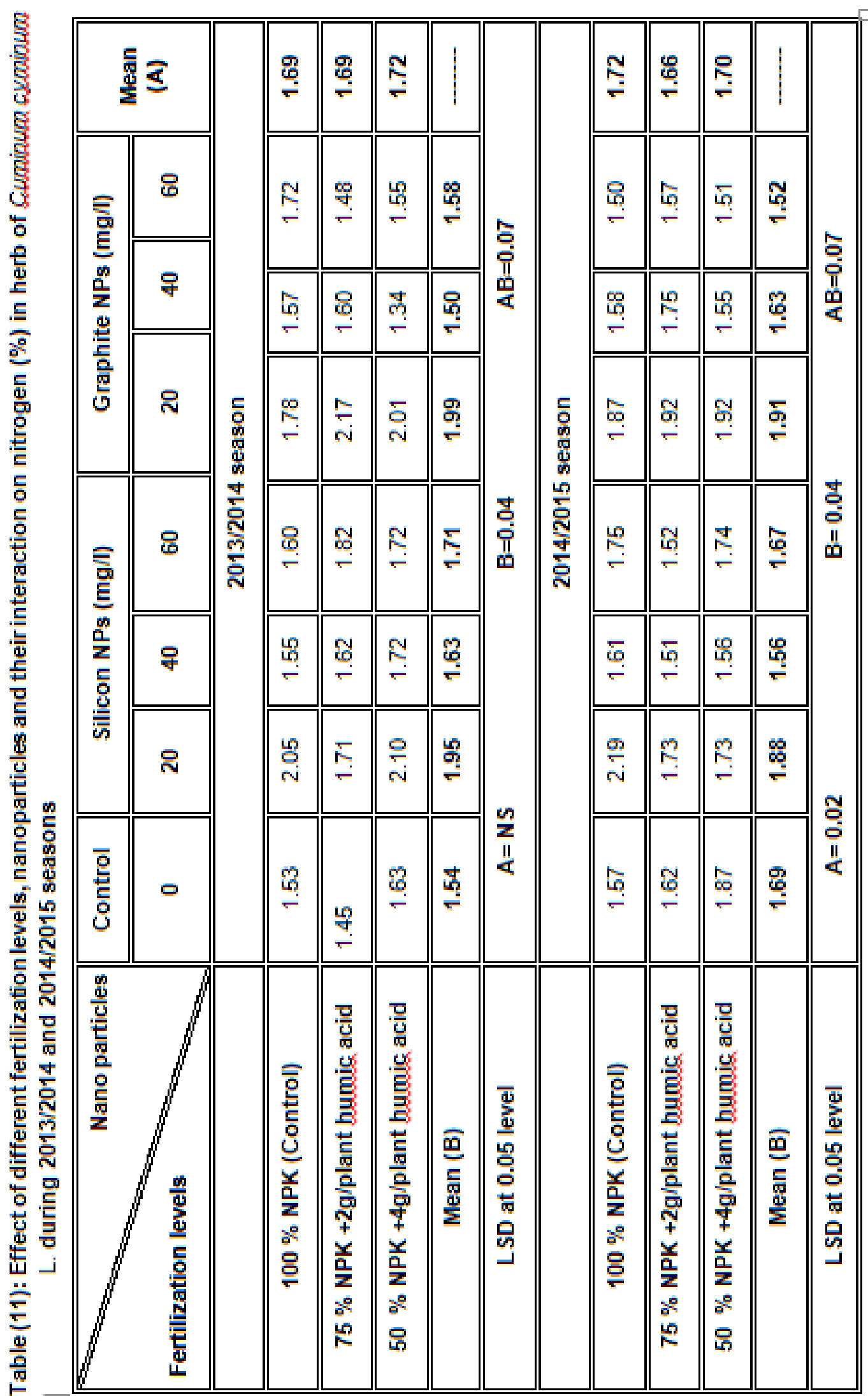


Effect of nano fertilization, chemical and humic acid on the 


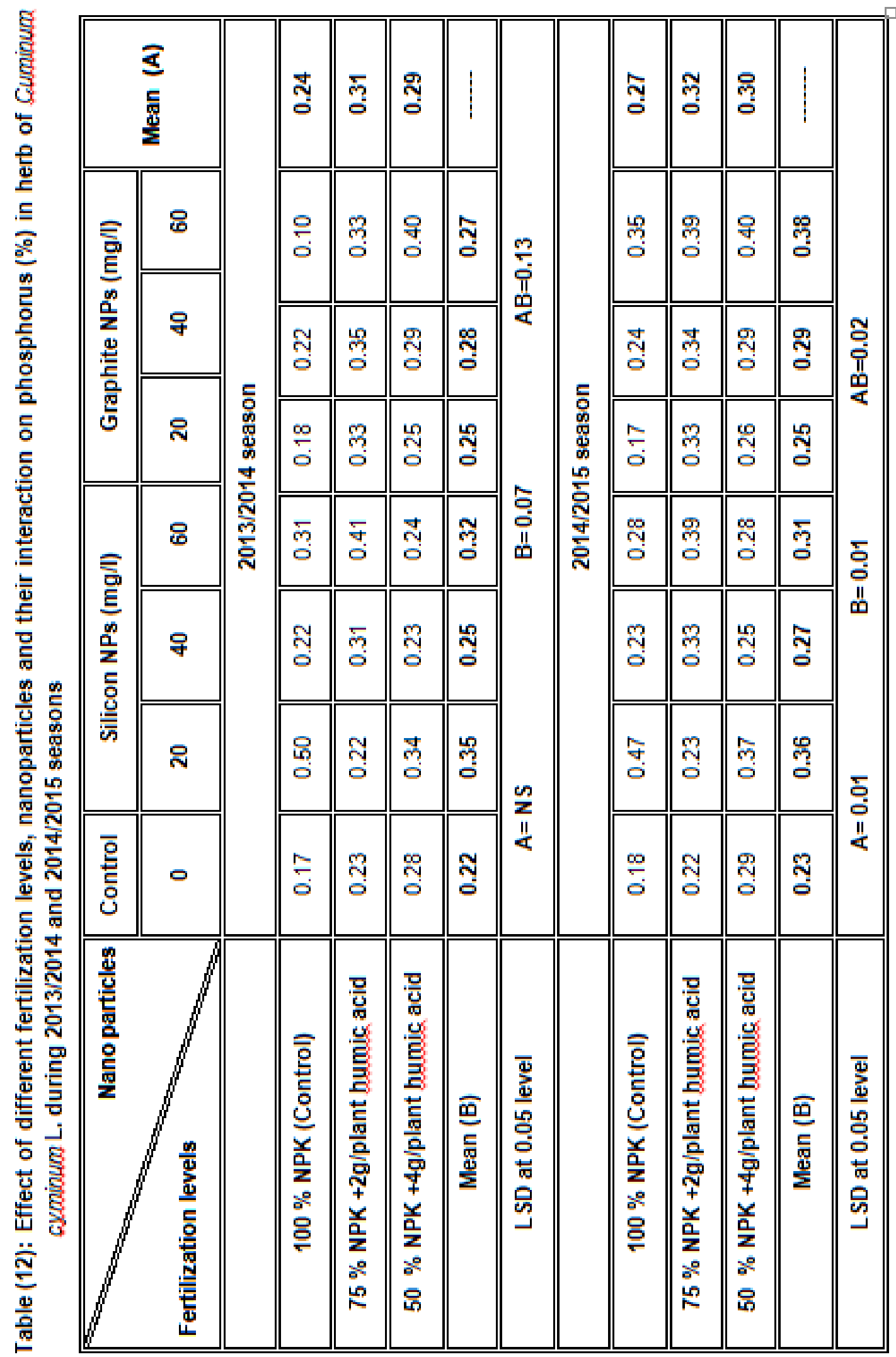


Effect of nano fertilization, chemical and humic acid on the 


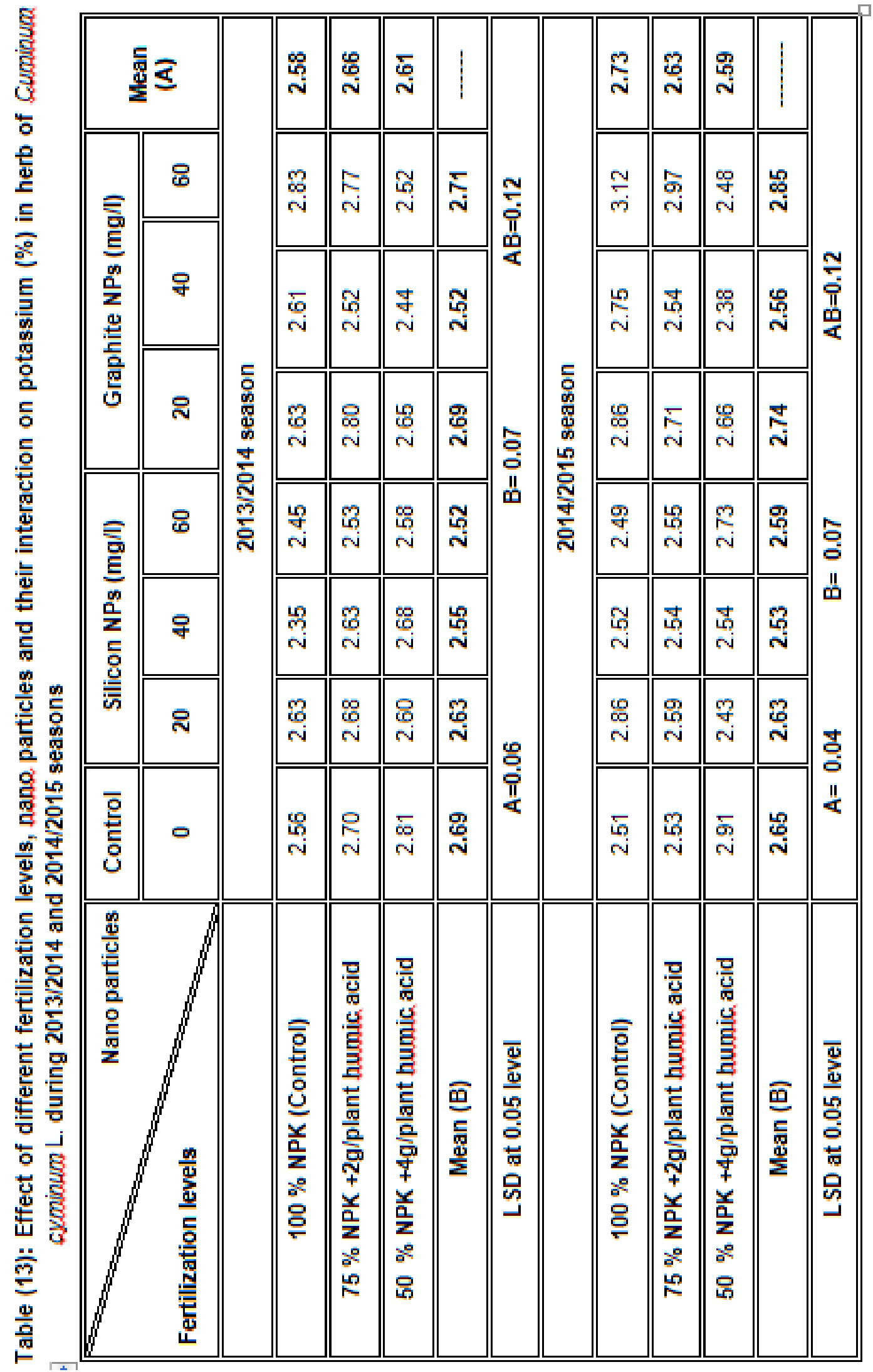


$\mathrm{mg} / \mathrm{l}$ graphite NPs. The highest values of phosphorus were registered from using $20 \mathrm{mg} / \mathrm{l}$ silicon NPs while potassium showed the highest percent for $60 \mathrm{mg} / \mathrm{l}$ graphite NPs in the two seasons. On the other hand, the least values of nitrogen resulted from $40 \mathrm{mg} / \mathrm{l}$ and $60 \mathrm{mg} / \mathrm{l}$ graphite NPs in both seasons, respectively. The highest Phosphorus values were observed for $40 \mathrm{mg} / \mathrm{l} \mathrm{silica}$ NPs or $20 \mathrm{mg} / \mathrm{l}$ graphite NPs and $20 \mathrm{mg} / \mathrm{l}$ graphite NPs in the $1^{\text {st }}$ and $2^{\text {nd }}$ seasons, respectively. However, the least values resulted from $60 \mathrm{mg} / \mathrm{l}$ silica NPs or $40 \mathrm{mg} / \mathrm{l}$ graphite NPs in the first season and $40 \mathrm{mg} / \mathrm{l}$ silica NPs in the second one. These results are in agreement with those of El Kereti et al. (2013) on Ocimum bacilicum.

For the interaction between different fertilization levels and nanoparticles, the highest values of $\mathrm{N}(\%)$ resulted from plants received $75 \% \mathrm{NPK}+$ humic acid $+20 \mathrm{mg} / \mathrm{l}$ graphite NPs and 100 $\% \mathrm{NPK}+20 \mathrm{mg} / \mathrm{l}$ silica NPs in the $1^{\text {st }}$ and $2^{\text {nd }}$ seasons, respectively. The least values resulted from the treatments of $50 \%$ NPK + humic acid with $40 \mathrm{mg} / \mathrm{l}$ graphite NPs and $100 \%$ NPK with $60 \mathrm{mg} / \mathrm{l}$ graphite NPs. Regarding phosphorous (\%), the highest values were attained from the plants received $100 \%$ NPK with $20 \mathrm{mg} / \mathrm{l}$ silica NPs in both seasons, while, the least values were obtained from using $100 \%$ NPK with $60 \mathrm{mg} / \mathrm{l}$ graphite NPs and $100 \%$ NPK with $20 \mathrm{mg} / \mathrm{l}$ graphite NPs. Concerning potassium percentage, the highest values were obtained from using $100 \%$ NPK with $60 \mathrm{mg} / \mathrm{l}$ graphite NPs in both seasons. On the other hand, the least values were recorded from using $75 \% \mathrm{NPK}+2 \mathrm{~g} / \mathrm{plant}$ humic acid with $60 \mathrm{mg} / \mathrm{l}$ silica NPs and $50 \%$ $\mathrm{NPK}+4 \mathrm{~g} /$ plant humic acid with $40 \mathrm{mg} / \mathrm{l}$ graphite NPs.

These results are in conformity to those of Gomaa and Youssef (2008) on caraway.

\section{5- Oil percentage:}

Data presented in Table (14) showed that using full dose of NPK gave the significantly highest values of oil percent. The least value were obtained from using $50 \% \mathrm{NPK}+$ humic acid in both seasons.

These results are in agreement with those of Juarez R. et al. (2011) on Thymus vulgaris L. and Nasirolesl and Safaridolatabad (2014) on dill.

Concerning nanoparticles treatments, data pointed out the highest oil percentage resulted from the treatments of $60 \mathrm{mg} / \mathrm{l}$ nano graphite in both seasons. On the other side, the treatment of $20 \mathrm{mg} / \mathrm{l}$ nano graphite and $60 \mathrm{mg} / \mathrm{l}$ nano silica recorded the significantly least oil percent. The augmintation of oil percentage from adding nanoparticles treatments may be due to that in the case of foliar spray, this would result in a high photosynthesis rate and consequently more production of carbohydrate precursors for essential oil synthesis.

For the interaction between different fertilization levels and nanoparticles treatments data showed that, the significantly highest oil \% resulted from treated plants with $100 \% \mathrm{NPK}+60$ $\mathrm{mg} / \mathrm{l}$ nano graphite in both seasons. The least value of oil \% resulted from the treatment of 100 $\%$ NPK + $20 \mathrm{mg} / \mathrm{l}$ nano graphite and $50 \% \mathrm{NPK}+$ humic acid with $60 \mathrm{mg} / \mathrm{l}$ nano graphite in the first and second season, respectively.

These results are in harmony with those El- Kereti et al. (2013) on sweet basil.

\section{Essential oil constituents:}

Components in volatile oil of different treatments were identified. Data indicated that, the major components which were identified were $p$-mentha-1-en-7-al as recorded $41.47 \%$ from the treatment of $75 \% \mathrm{NPK}+2 \mathrm{~g} /$ plant humic acid with $40 \mathrm{mg} / \mathrm{l}$ silica NPs followed by $50 \% \mathrm{NPK}+$ $4 \mathrm{~g} /$ plant humic acid and $60 \mathrm{mg} / \mathrm{l}$ graphite NPs and cumin aldehyde as recorded $36.67 \%$ from the treatment $100 \%$ NPK with $20 \mathrm{mg} / \mathrm{l}$ graphite NPs. On the opposite, the least values were obtained from the treatment of $100 \%$ NPK with $20 \mathrm{mg} / \mathrm{l}$ silicon NPs as recorded $31.28 \%, 23.82$ $\%$, respectively. The other components which were identified in the oil were $\alpha$ - thujene, $\beta$ - 
pinene, $\alpha$ - phyllandrene, $P$ - cymene and $y$ - terpinene (as showen in Fig. 3: a,b,c,d and $f$ ). These results are in harmony with those of Beis et 
Effect of nano fertilization, chemical and humic acid on the .....................

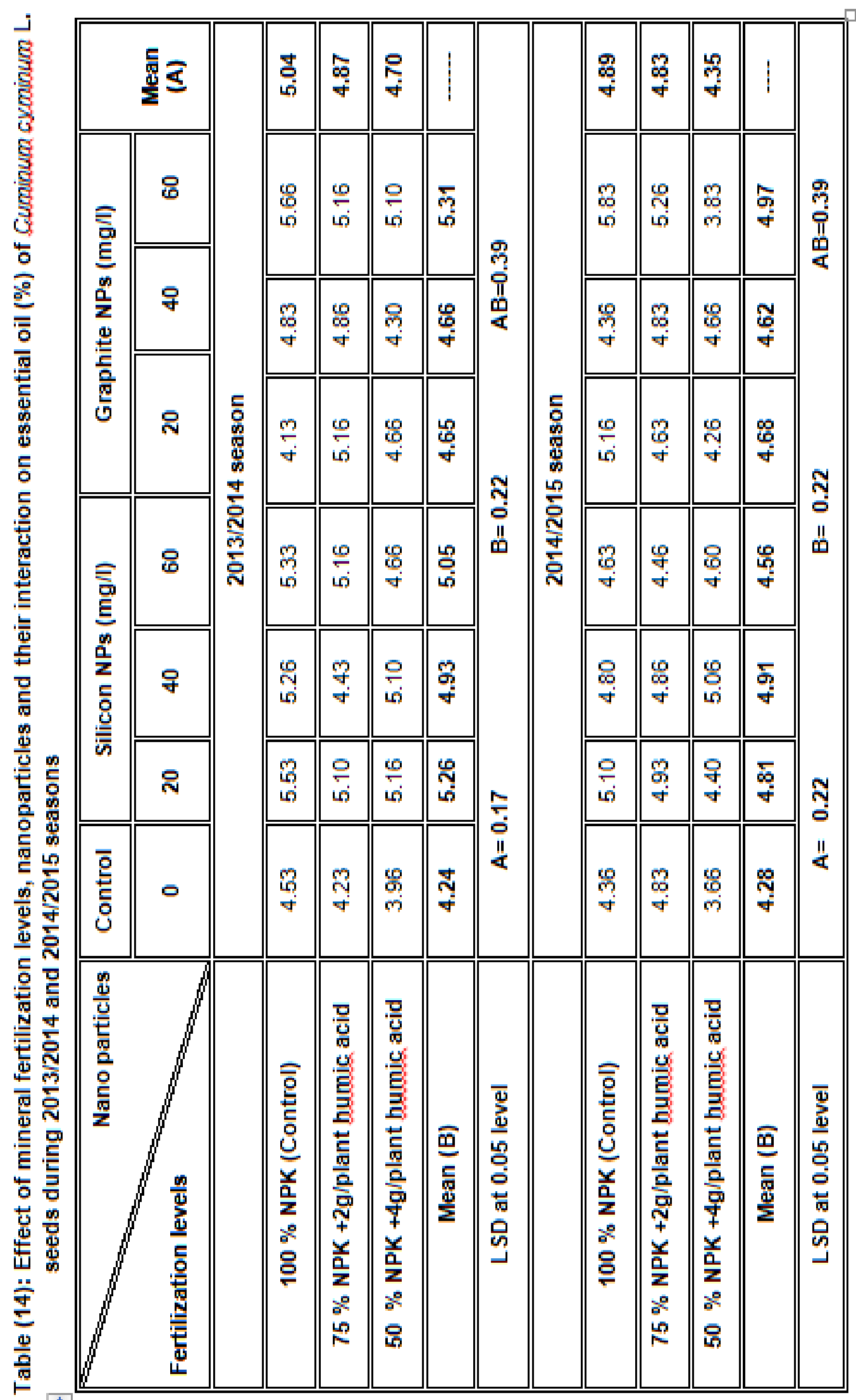




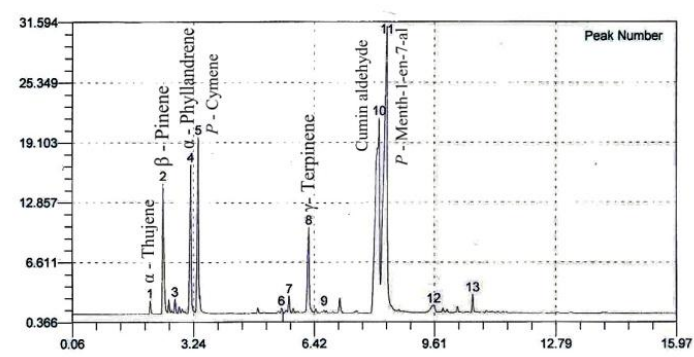

A) $100 \% \mathrm{NPK}$ (control) without nano.

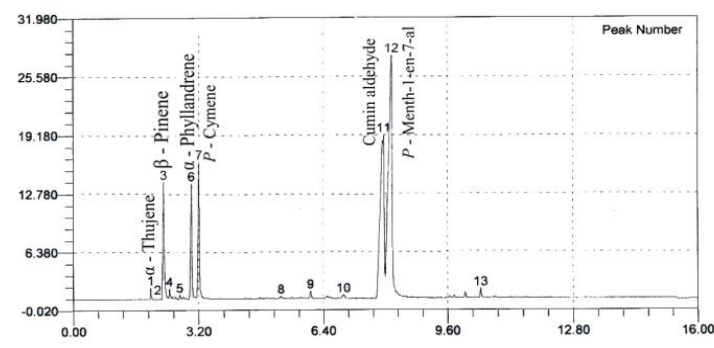

B) $75 \% \mathrm{NPK}$ + humic acid + $40 \mathrm{mg} / \mathrm{l}$ nano silicon.

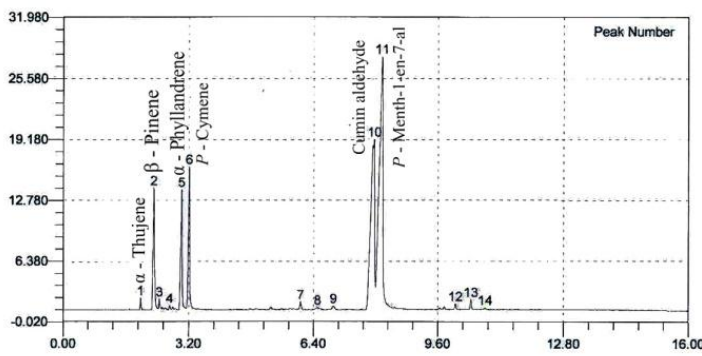

C) $50 \% \mathrm{NPK}$ + humic acid + $60 \mathrm{mg} / \mathrm{l}$ nano graphite

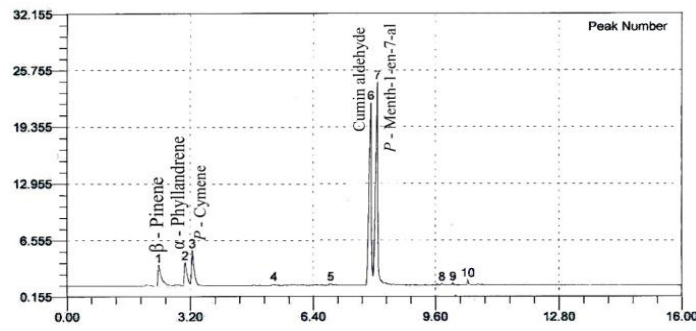

D) $100 \% \mathrm{NPK}+20 \mathrm{mg} / \mathrm{l}$ nano graphite.

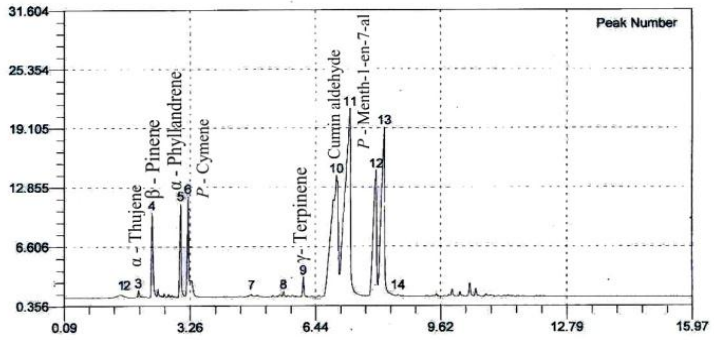

F) $100 \% \mathrm{NPK}+20 \mathrm{mg} / \mathrm{l}$ nano silicon 
Fig (3): Effect of different fertilization kinds and levels on cumin essential oil composition.

al. (2000) and lacobellis et al. (2005) who reported that $p$-mentha-1,4dien-7al as the major component with a concentration 27.4 $\%$ whereas cumin aldehyde secured second rank with a concentration of $16.1 \%$.

\section{REFERENCES}

Agrawal, S. and P. Rathore (2014). Nanotechnology pros and cons to agriculture: A Review. Int. J. Curr. Microbiol. App. Sci, 3(3): 43-55.

Amin, I.S. and M.A. Abd El Wahab (1999). Effect of chemical fertilization on Cuminum cyminum oil constituents under North Sinia conditions. Annals of Agric. Sci., Moshtohor, 37(1): 485-500.

Baytop, T. (1989). Therapy with Plants in Turkey, Istanbul University Publication No. 3255. Istanbul.

Befrozfar, M. R., D. Habibi, A. Asgharzadeh, M. S. Shoae and M. R. Tookallo (2013). Vermicompost, plant growth promoting bacteria and humic acid can affect the growth and essence of basil (Ocimum basilicum L.). Annals of Biologi. Res., 4(2):8-12.

Behera, S., S. Nagarajan and L. J. M. Rao (2004). "Microwave heating and conventional roasting of cumin seeds (Cuminum cyminum L.) and effect on chemical composition of volatiles "Food Cheim., 87, 25-29.

Beis, S.H., T.N. Azcan, I.T. Ozek, I.M. Kara and K.H.C. Baser (2000). Production of essential oil from cumin seeds. Chem $\mathrm{N}$ at Compd, 36: 265-268.

Black, C.A. (1983). Methods of Soil Analysis. Part land 2.Soil Sci. Soc. Amer. Inc. Pulp., Madison, Wise fU.S.A.

Chen, Y. and T. Avaid (1990). Effect of humic substances on plant growth. In MacCarthy, P., C. E. Clapp, R. L. Malcolm and P. R. Btoom (Eds): Humic Substances in Soil and Crop Sciences: Selected Reading. Soil Science Society of America, Madison, 161- 187.
Dorer, S. P. and C. H. Peacock (1997). The effect of humate and organic fertilizer on establishment and nutrition of creeping bentgrass putting greens. Inter. Turfgrass Soci. Res. J., 8: 437-443.

El- Foly Amal S., Boshra A. El- Sayed and S.M. Shahin (2014). Effect of foliar spraying with humic acid chelated microelements on growth and quality of goodluck (Cordyline terminalis (L.)Kunth.)plant. Minufiya J. Agric.Res.,39. 1(2): 205-213.

El-Kereti, M.A., S.A. El-Feky, M.S. Khater, Y.A. Osman and E.A. El-sherbini (2013). $\mathrm{ZnO}$ nanofertilizer and $\mathrm{He} \mathrm{Ne}$ laser irradiation for promoting growth and yield of sweet basil plant. Recent Patents on Food, Nutrition\& Agriculture, 5: 1-13.

Gomaa, A.O. and A. S. M. Youssef (2008). Efficiency of bio and chemical fertilization in presence of humic acid on growth performance of caraway. Proe Scientific Conference of Agric.and Biol. Res. Division under the theme. May 5-6, Hort. Dept., Fac. Agric., Moshtohor, Benha University, Egypt.

Gruenwald, J., T. Brendler and C. Jaenicke (2004). PDR for Herbal Medicines, 3 rd Edition. Medical Economics Company, 245 - 246, New Jersey.

Guenther, H. (1960). The Essential Oil. D. Van Nostrand Company New York, Torento, London, Vol. 1.

Helgi, O. and S.A. Rolfe (2005). The Physiology of Flowering Plants. $4^{\text {th }}$. Edn., Cambridge University Press, Cambride U K., 392 pp.

lacobellis, N.S., P. Lo Cantore, F. Capasso and F. Sentore (2005). Antibacterial activity of Cuminum cyminum L. and Carum carvi L. essential oils. J Agric Food Chem., 53: 57-61.

Juarez, R., C.R., L. E. Craker, Ma.De las N. R. Mendoza and Y. J. A. Aguilar- Castillo (2011). Humic substances and moisture content in the production of biomass and 
bioactive constituents of Thymus vulgaris L. Rev. Fitotec. Mex., 34(3): 183-188.

Kole, C., P. Kole, K.M. Randunu, P. Choudhary, R. Podila, P.C. Ke, A.M. Rao and R.K. Marcus (2013). Nanobiotechnology can boast crop production and quality: firt evidence from increased plant biomass, fruit yield and phytomedicine content in bitter melon (Momordica charantia). BMC Biotechnology, 13(37): 1472-6750.

Kottegoda, N., I. Munaweer, M. Madusanka and V. Karunaratne (2011). A green slow-release fertilizer composition based on urea-modified hydroxyapatite nanoparticles encapsulated wood. Current Science, 101 (1): 73-78.

$\mathrm{Li}, \mathrm{R}$. and Z-T. Jiang (2004). "Chemical composition of the essential oil of Cuminum cyminum L. from China "Flav. Fragr. J., 19, 311-313.

Nasiroleslami, Ehsan and S. Safuridolatabad (2014). The comparison of organic and biologic fertilizers effects on growth and essential oil of dill (Anethum graveolens L.). International Journal of Biosciences, 5(7): 65-74.

Rawson, H.M., M.J. long and R. Munns (1988). Growth and development in $\mathrm{NaCl}$ treated plants. J Plant Physiol., 15: 519527.

Richards, L.A. (1954). Diagnosis and Improvement of Saline and Alkaline Soils U.S.D.A. Agric. Hand Book No. 60. Gov. Print. Off.

Said, A., B. S. Rabo, A. B. Mustapha, S. Y. Simon and I. L. Hamma (2015). Influence of NPK fertilizer on the performance of roselle (Hibiscus sabdariffa (L.) in Samara, Zaria. Nigerian Journal of Agriculture, Food and Environment, 11(3):61-64.

Snedecor, G. W. and W. G. Cochran (1980). Statistical Methods. $7^{\text {th }}$ ed. The lowa State, Univ. Press. lowa, U. S. A.

Watanabe, F.S. and S.R. Olsen (1965). Test of an ascorbic acid method for determining phosphorus in water and $\mathrm{NaHCO}_{3}$ extracts from soil. Soil Science Society Proceedings, PP. 677-67.

Wellburn, A. R. (1994). The spectral determination of chlorophylls $a$ and $b$, as well as total carotenoids, using various solvents with spectrophotometers of different resolution. J. Plant Physiol., 144: 307:313. 
تأثير معاملات التسميذ بالنانوو التسميد الكيماوى و حمض الهيوميك على النمو الخضرى و التركيب الكيماوى و محصول الزيت فى نبات الكمون

حسنى محمد اللبان (1) ، فردوس منيسى(2) ، شادية أحمد قطب(3) ، محمد إبراهيم فتوح(1) ،

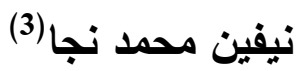

(1) قسم البسانين - كلية الزراعة - جامعة طنطا

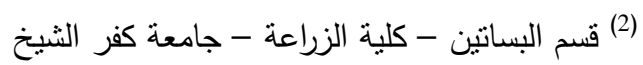

(3) معهز بحوث البساتين

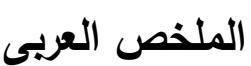

أجريت هذه التجربة فى مزرعة خاصة بالقرب من المحلة الكبرى (محافظة الغربية) أثناء موسمى 2013-2014 ، 2014-2015 لدراسة تاثير مستويات نسميدية مختلفة بالاضافة للتسميد بالنانو سليكون و النانو جرافيت على بلى النمو الخضرى و التركيب الكيماوى و محصول الزيت و تركيبه لنبات الكمون. و قد تم تقدير حجم جزيئات النانو باستخدام الميكرسكوب الاككترونى و تم رش النبات بثلاث تركيزات 20، 40، 60 ملليجرام/ لتز من كلا المادتين

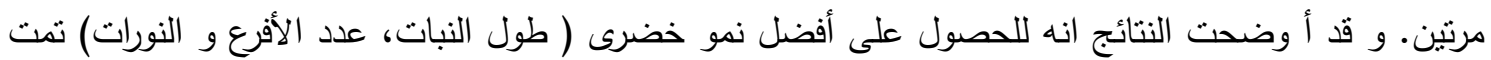

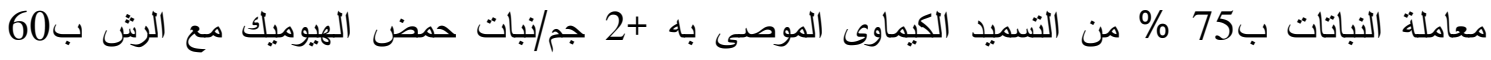
ملليجرام/ لتز نانو جرافيت، و نم تحقيق اعلى قيمة لكلورفيل أهب من معاملة النباتات ب 75 \% من التسميد

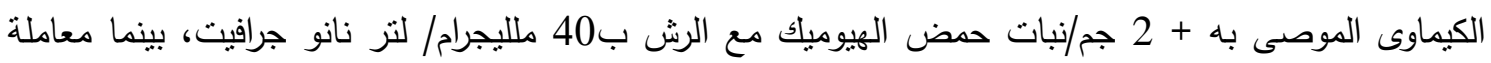

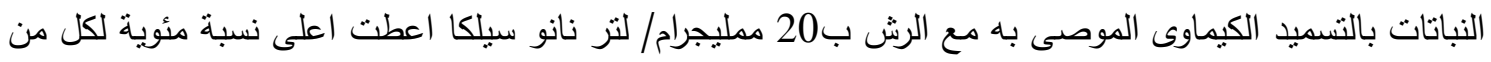
النيتروجين و الفوسفور و للحصول على اعلى نسبة مئوية للزبت و البوتاسيوم يجب معاملة النباتات بالتسميد

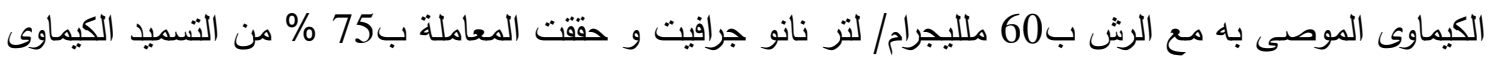
الموصى به + 2 جم/نبات مع الرش ب40 ملليجرام/لتر نانو سليكا اعلى نسبة مئوية من مركب بيتا-مينا مينثا-1، 7

تبعا للنتائج السابقة نوصى بالآتى:

1- للحصول على أفضل نمو خضرى تتم معاملة النباتات ب 75 \% من النسميد الكيماوى الموصى به + 2 جم/نبات حمض الهيوميك مع الرش 60 ملليجرام/لتز نانو جرافيت. 2- للحصول على أعلى محصسول زيت تنتم معاملة النباتات بالتسميد الكيماوى الموصسى بـه مـع الرش بـ 60 ملليجرام/ لتر نانو جرافيت. 